\title{
Wage policies in the public sector during wholesale privatization
}

\section{Does the transition to market economies imply growing wage inequality and, if so, along what dimensions?}

Keywords: public sector, wage compression, economic transition, wage policies

\section{ELEVATOR PITCH}

Examining the implications of changes in public sector wage-setting arrangements due to privatization is a relatively new area of economics research, with few studies having analyzed the effects of public sector restructuring on relative wages in developed countries. There is, however, a growing empirical literature that measures the effects of transitioning from central planning to marketbased systems on public-private sector wage differentials. Policymakers can learn from this evidence about the ways in which ownership transformation affects the distribution of wages in both the public and private employment sectors.

\section{KEY FINDINGS}

\section{Pros}

๑ The transition from centralized to marketbased wage-setting can be viewed as a natural experiment that may help policymakers better understand and adjust wage-setting mechanisms in the public sector.

๑ The public sector wage penalty tends to decline during transition, whereas wage inequality between high- and low-educated workers increases.

$\oplus$ Accounting for sectoral differences in worker and job characteristics across the wage distribution allows policymakers to provide workers with effective incentives.
Changes in men's average public-private sector wage gap in transition economies (\%)

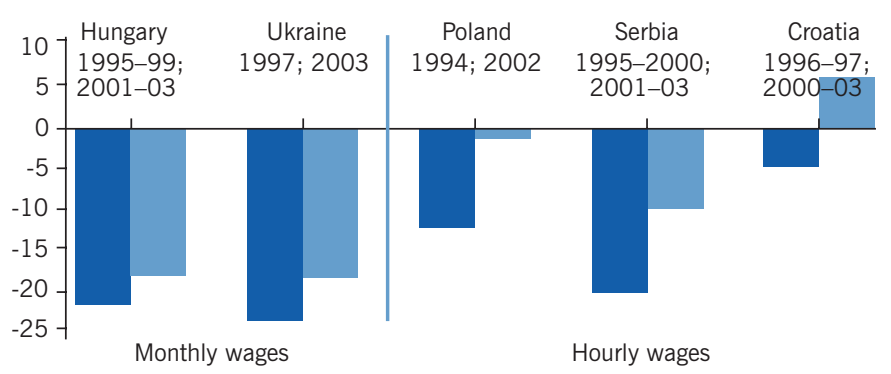

Note: Male and female workers for Poland; wage gap in 2002 not statistically different from zero.

Source: For Hungary, HUWS data: [1]; for Ukraine, ULMS data: [2]; for Poland, LFS data: [3]; for Serbia, LFS data: [4]; for Croatia, author's own calculations based on LFS data.

\section{Cons}

- The start of transition revealed pronounced public sector wage compression, with lower wages than in the private sector, especially for the highly educated.

- Public reforms that are focused on average wages may create a premium for workers at the bottom of the wage distribution, and a penalty for those at the top, potentially straining public finances and adversely affecting performance and turnover of highly educated workers.

- Cross-country comparisons of public-private wage differentials are difficult to make due to differences in sector definitions, sample selection, and the availability of data.

\section{AUTHOR'S MAIN MESSAGE}

Empirical evidence confirms that different sectors paid similar workers different wages during economic transition. Carefully designed wage policies should consider the distributional aspects of wages for two reasons. First, wagesetting mechanisms imply that wages are more compressed in the public sector than in the private sector, which means that estimates of the average public-private wage differential may not give the full picture. Second, transition from a largely public sector wage-setting system to a competitive market structure likely requires widening the public sector wage distribution. 


\section{MOTIVATION}

Under central planning, the public sector in transition countries employed nearly the entire workforce, and wage equality was one of the major social principles in wage determination. Economic transition involved labor market conversion from public sector ownership to a competitive market structure by means of wholesale privatization.

In contrast to market economies, where the public sector average wage is more likely to be above the private sector average wage, comparisons of public and private sector wages for similar workers during early transition typically estimate a negative public-private sector wage gap (as shown for the 1990s by the illustration on page 1). As transition countries progressed to reach the labor market functionality of developed economies, evidence shows that the wage penalty decreased, even becoming a premium in some countries (as shown for the 2000s by the illustration on page 1). Empirical evidence on changes in public-private wage gaps during transition provides useful insights into the implications of different wage-setting arrangements on wage inequality between the public and private sectors.

\section{DISCUSSION OF PROS AND CONS}

\section{Why should pay differ between the public and private sectors?}

Policymakers need to ensure that wage determination in the public sector provides competitive compensation relative to the private sector. If the public sector lacks the capacity to match private sector wages, it will have difficulty hiring and retaining a highquality workforce. Consequently, the quality of public services may deteriorate, and problems such as corruption and worker turnover could become more prevalent, adversely affecting the entire economy. However, if the public sector pays higher wages, the private sector could face difficulties in recruitment and encounter upward pressure on wages as workers queue to enter the public sector. Further adverse effects on employment could be caused by increases in taxes or reductions in public investments necessary for economic growth in order to finance high public wages. A rise in public sector wages during political cycles or economic expansion may be hard to reverse in periods of recession and may lead to an increase in informal sector activities.

Simple comparisons of raw public sector wages with those in the private sector, as are typically reported in policy documents, can be very deceptive. Empirical evidence shows that higher wages in public jobs can largely be explained by job composition and worker characteristics. Public sector establishments are, on average, larger than private sector firms, and the majority of jobs in the public sector in OECD countries are also now clerical, with only a very small fraction of manual jobs. Public sector workers are also found to be, on average, better educated, older, and more risk averse than private sector workers. When these characteristics are taken into account, the public sector wage premium either decreases or turns into a penalty relative to the private sector.

A variety of methodological approaches are used to control for compositional differences between the two sectors. One common approach is to pool data across workers in both sectors in the wage equation that includes a set of worker and job characteristics, and a dummy variable indicating whether a worker has public sector status or not. A second, less restrictive, approach estimates wage equations for the public and private sector 
samples separately. In this case the wage gap is decomposed into two components. One is the difference in worker and job characteristics; the other is the difference in the returns to characteristics, and represents the wage gap upon which policymakers should focus. In a third approach, the wage gap estimates can be obtained using methods that correct for potential non-random sector selection based on unobserved worker characteristics (such as ability, risk aversion, and family influence). These approaches can be applied at the mean and at different points of the wage distribution.

Although most of the characteristics that explain compositional disparities between sectors are common to both transition and developed market economies, there are some important differences. For example, differences in the union status between the public and private sectors are important in market economies, whereas unions in transition economies are found to have only a modest influence on wage-setting [4].

An important feature in transition economies is a potential large disparity in non-wage benefits between the two sectors, such as meal and travel allowances, subsidies, payments in-kind, and bonuses, which must be accounted for when analyzing sectoral wage gaps [4]. Moreover, wage arrears are widespread in economic transition and may also affect the wage gap due to non-random distribution between sectors.

Systematic wage differences between public and private sectors could potentially exist due to intrinsic differences in wage-setting behavior. Specifically, public sector workers may be underpaid relative to their private sector counterparts if the public sector holds market power in wage-setting as a result of its being the dominant employer. In market economies, this is typical for selected sectors, such as education, health care, law enforcement, and public administration. In communist economies, the public sector was the employer of nearly the entire workforce. Prior to transition, wages were not directly linked to enterprise performance, but were centrally determined with minimum and maximum wages, which created a very egalitarian wage distribution. Economic transition meant that although the government might initially continue to impose restrictions on pay, workers could opt to change their sector of employment, as there would now be a private sector alternative in which wages would be determined based on profit maximization. The literature suggests that private sector expansion and an increase in demand for skills during transition caused significant growth in wage inequality (faster than in other OECD economies) [3]. Wage differentials were one of the key variables in labor markets in transition economies.

\section{Changes in the public sector wage gap during transition}

A number of studies carried out at the initial stages of economic transition found that public sector workers earned, on average, lower wages than their private sector counterparts. This result is robust across different methodological approaches, definitions of public sector, wage definitions (monthly, hourly, before or after tax), gender, and data sources (whether self-reported or employer-provided). In most countries the negative gap between public and private sector wages narrows over time [5].

The illustration on page 1 presents results from studies that estimate the mean publicprivate sector wage gap, conditional upon observed worker and job characteristics. The selection of studies for this comparison was based on the use of a common method of 
estimation across countries in two transition periods: the 1990s and early 2000s. The periods relate to ownership transformation and public sector wage reforms respectively. In all sources used for the illustration on page 1, regression specifications include experience and/or tenure and education, as well as a range of other relevant variables. However, the purpose of the illustration is just to show the change in the public-private wage gap between the two periods for each of the selected economies, rather than to make a cross-country comparison of the size of the wage gap. This is primarily due to available data sets that determine sample variables and sector definitions used in the estimations. For example, in studies for Hungary and Ukraine the public sector includes budgetary institutions (public administration, health, and education), whereas for Poland, Serbia, and Croatia, it includes both budgetary institutions and state-owned enterprises.

Although the illustration on page 1 presents estimates from self-contained studies that focus on different countries and use different sources of microdata, a common story can be drawn: there was a negative public-private sector wage differential during the 1990s that declined in the early 2000 s. The study on Poland finds that the gap changed from $-11 \%$ to $0 \%$ [3]. In Serbia, it changed from $-18 \%$ to $-9 \%$ [4], in Croatia from $-4 \%$ to $+6 \%$, and in Hungary from $-20 \%$ to $-16 \%$ [1]. The study on Ukraine estimates a change from $-21 \%$ to $-16.5 \%$, and shows that estimates obtained using longitudinal data remained very close to cross-sectional estimates (-20.5\% from 1997-2003) [2]. The same study (not shown in the illustration) finds that the difference was greater for female employees, indicating that sorting into the public sector based on individual preferences is greater for female than for male employees.

Other studies that correct for sector selection also estimate negative public-private wage gaps. A further study on Poland reports the wage gap to be $-7 \%$ for men and $-10 \%$ for women in 1996, after correcting for lower entry costs into the private sector for younger individuals [6]. Research on Yugoslavia estimates a $-9.4 \%$ wage gap for male employees in 2000 after correcting for differences in sectoral job security and associated benefits [7].

\section{Why is it important to look beyond the comparisons at the mean?}

A closer look at data from the same studies used in the illustration on page 1 suggests discrepancies in the size of the public wage gap at three different points of the wage distribution.

Figure 1 reveals an increasing public sector wage penalty along the wage distribution. In other words, workers with high wages are more underpaid than those with low wages when both are compared with their private sector counterparts. Whilst public sector wage compression is also typical for developed countries, a comprehensive literature survey suggests greater compression in transition economies [5]. Consequently, higher paid workers had greater incentives than lower paid workers to search for better opportunities in the private sector. The implication of this for policymakers is clear: appropriate wage reforms are necessary to retain the most skilled workers, as well as to prevent corruption and deterioration in the quality of public services. 
Figure 1. Public-private wage gap by wage percentile
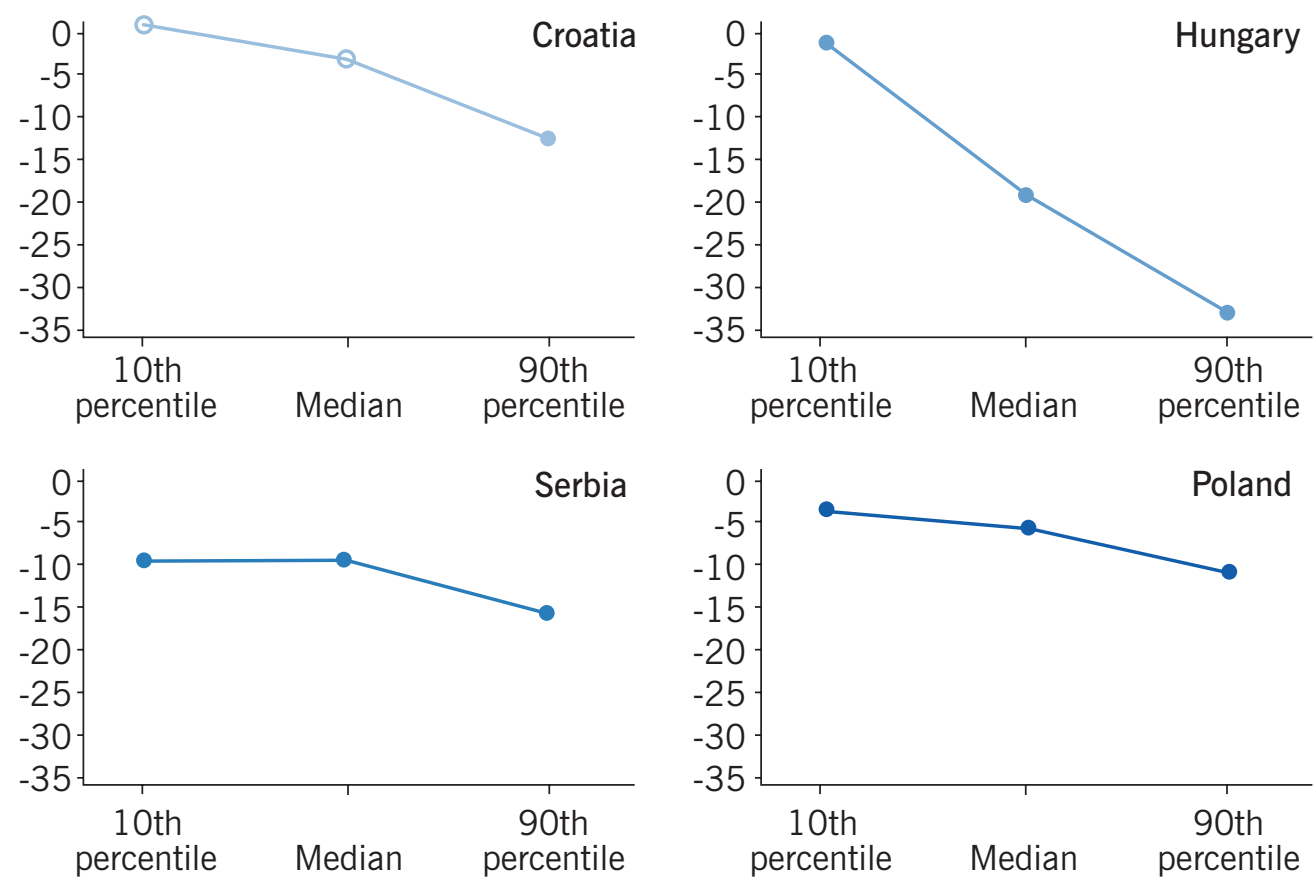

Note: Points with empty markers are not statistically different from zero.

Source: For Croatia, author's own calculations based on LFS data: 1996-1997; for Hungary, HUWS data: 19952003 in Lausev, J. Public-Private Earnings Differentials during Economic Transition in Hungary. Budapest Working Papers on the Labour Market No. BWP-201/2, 2012 [1]; for Poland, LFS data: 1998 in Newell, A., and M. W. Socha. The Polish Wage Inequality Explosion. IZA Discussion Paper No. 2644, February 2007 [3]; for Serbia, LFS data: 1995-2003 in Nikolic, J. "Effect of large-scale privatization on public sector pay gap in a transition economy." Economics of Transition 22:4 (2014): 759-781 [4].

\section{Effects of changes in public sector wage policies}

A number of studies have analyzed changes in public sector wage-setting in transition economies (see Wage reforms in Serbia and Hungary). One such study on Serbia finds that the public-private wage gap at the mean in 2004-2008 was close to zero for workers with tertiary education, while a premium emerged for workers only educated to either a primary or secondary level (14\% and $13 \%$ for males respectively) [4]. Similar research for Hungary shows that the wage gap at the mean changed from a penalty in 2000 into a premium in 2004 for workers educated to below tertiary level (-13\% turns into $14 \%$ for workers with primary and vocational education, and -22\% turns into $10 \%$ for high school graduates), while those with tertiary education saw the largest improvements relative to their private sector counterparts (the gap changed from $-43 \%$ in 2000 to $-4 \%$ in 2004) [8]. This suggests an increase in public sector wage inequality.

The literature from Estonia, Serbia, and Russia consistently reports faster growth of public sector wages relative to private sector wages for workers at the top end of the wage distribution than for workers at the bottom end [4], [9], [10]. For example, research on Estonia estimates that in 1989 a $-23 \%$ public wage gap existed at the 10 th percentile, and a $-77 \%$ gap at the 90 th percentile. Ten years later, in 1998, workers at the 10th percentile enjoyed a $13 \%$ public sector premium, whereas those at the 90 th percentile saw the gap 
reduce to $-9.4 \%$. In Russia, policy changes to redistribute wage funds toward the most skilled government workers were undertaken only recently, in 2012. Nevertheless, recent research has also shown that the public sector wage penalty has decreased, and that the largest relative gain is observed for those placed in higher percentiles [10].

\section{Wage reforms in Serbia and Hungary}

The public sector in Serbia during the 1990s suffered from limited scope for wage flexibility, especially in relation to skilled workers, which caused widespread problems in employee motivation. Changes in wage-setting arrangements were introduced by the Labor Law in 2001, tightening the link between pay and performance, and giving employers greater discretion in the determination of individual wages, and thereby the ability to encourage highly educated workers (Ognjenović, 2002). The government wagesetting policy implemented a "catch-up" for some skilled professions from 2001, such as for those working in public education, public health, and public services. The increase in public sector real average wages reached $26 \%$ during the political cycle in 2006-2007, affecting around a quarter of the total labor force (Mijatović, 2008).

In Hungary, the early 2000s were also marked by episodes of public sector wage reform. The public sector real average wage increased by $29 \%$ between 2002 and 2003, affecting around $20 \%$ of the total labor force (Altwicker-Hámori and Köllö, 2013). The wage scale was revised and a minimum monthly wage for tertiary graduates was introduced, whereby the wages of tertiary graduates in the lowest education and seniority brackets were set to be twice the statutory minimum wage. According to the literature, the motivation behind this wage reform was to combat losses of highly skilled workers and impede negative selection of labor quality into the public sector (Telegdy, 2006).

Sources: Ognjenović, K. Analysing Determinants of Wage and Wage Discrimination: The Example of Serbia. GDN Research Competition Project GRCII+17, 2002; Mijatović, B. (ed.). Reforms in Serbia: Achievements and Challenges. Belgrade: Center for Liberal-Democratic Studies, 2008; Altwicker-Hámori, S., and J. Köllö. "Hungary: Public sector labour market from crisis to crisis." In: Vaughan-Whitehead, D. (ed.). Public Sector Shock. The Impact of Policy Retrenchment in Europe. Cheltenham, UK: Edward Elgar and International Labour Office, 2013; pp. 300-336; Telegdy, À. "The effect of the public sector wage increase on the publicprivate relative wages." In: Galasi, P., and G. Kézdi (eds). The Hungarian Labour Market 2006. Budapest: Institute of Economics, Hungarian Academy of Sciences, Hungarian Employment Foundation, 2006; pp. 60-68.

More detailed analyses by educational qualification and gender in Hungary reveal that university graduates in the 10th percentile saw the greatest relative financial gain between the 1990s and early 2000s when compared with all other groups of workers [1]. Wage reforms are found to have caused a premium at the 10th percentile, while the penalty at the 90th percentile changed little, as shown in Figure 2 [12]. For policymakers, the lesson from this evidence is that although Hungarian public sector wage reforms increased inequality between the average wages of workers with different educational qualifications, revisions of wage scales led to wage compression among workers with the same educational qualification, especially for university graduates.

In sum, several adverse effects should be highlighted based on the evidence presented in Figure 2. A large starting wage premium for high-skilled workers in the 10th percentile is likely to attract more competent young university graduates to enter the public 
Figure 2. Public-private sector wage gap for different skill levels

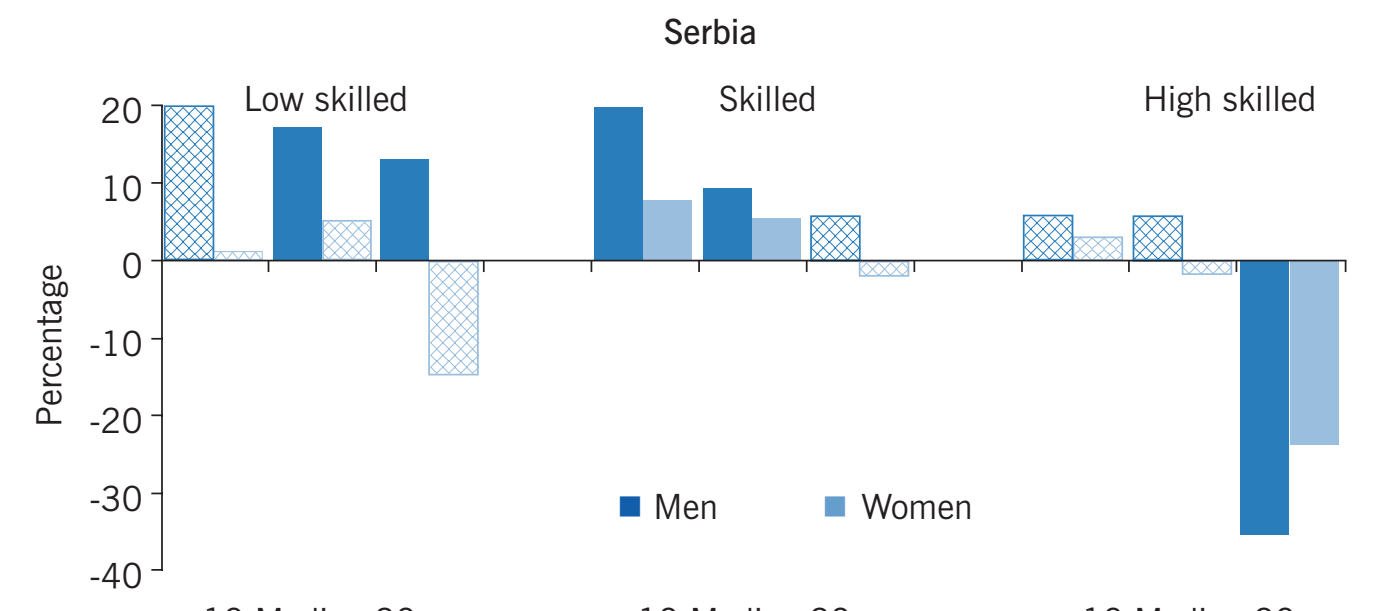

10 Median $90 \quad 10$ Median $90 \quad 10$ Median 90

Hungary

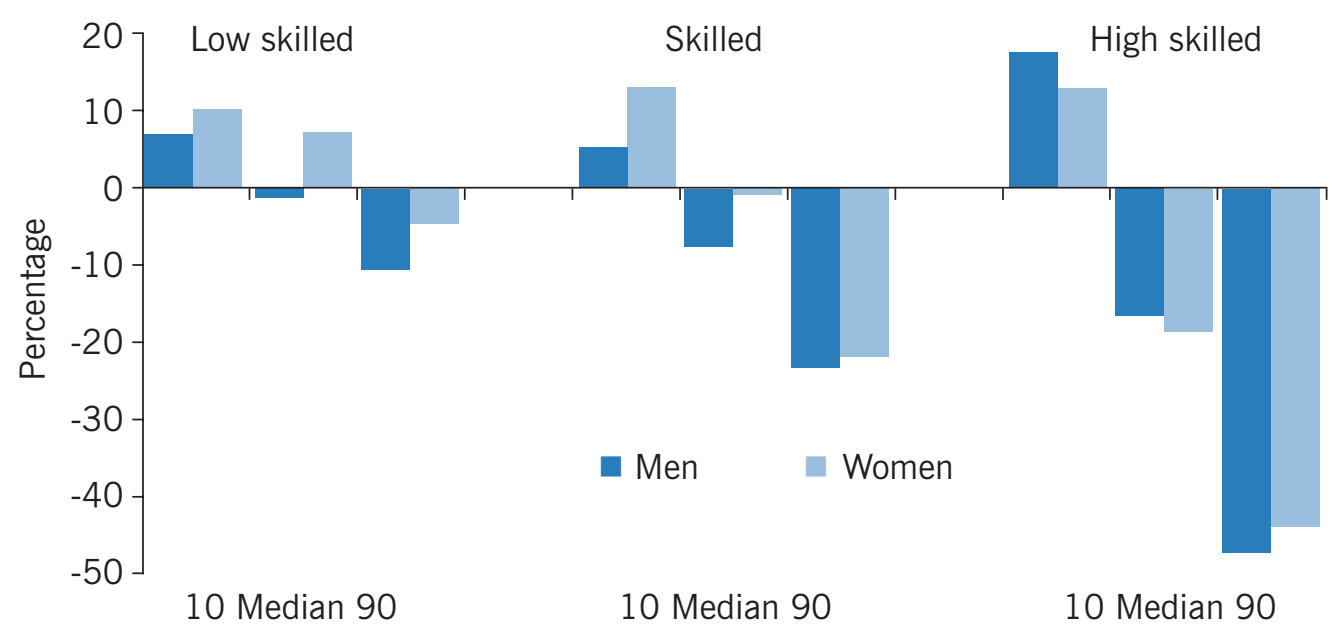

Note: Unfilled bars are not statistically different from zero. The low-skilled group includes workers with primary educational qualification or less. The skilled group in Serbia includes workers with high school qualifications and college degrees; for Hungary it includes vocational and high school degrees. The high-skilled group includes workers with a university degree and above. Hourly wages for Serbia and monthly wages for Hungary.

Source: For Serbia, LFS: 2004-2008 data in Lausev, J. "Public sector pay gap in Serbia during large-scale privatisation, by educational qualification." Economic Annals LVII:192 (2012): 7-24 [11]; for Hungary, HUWS: 2004-2006 data in Lausev, J. "The effect of austerity measures on public-private sector wage gap in Hungary." In: Global Crisis to Economic Growth: Which Way to Take? Belgrade: University of Belgrade, 2012 [12].

sector, as in Hungary, while the private sector will face hiring difficulties as a result. Additionally, increasing penalties at higher percentiles of the wage distribution is likely to cause greater worker turnover, increase disincentives, foster moonlighting, and lead to underperformance at the more senior level. However, higher public sector than private sector wages for workers educated to less than a tertiary education, as in Serbia, will likely reduce public sector efficiency, strain its finances, and hinder private sector job creation. 
The 2008 global financial crisis further challenged public wage bill sustainability and revealed weaknesses of pre-crisis wage reform processes in transition countries. An analysis of EU countries reported that the average for the public-private wage gap was $3.6 \%$ in 2010 [13]. The same study found that Poland and Slovenia were the only EU posttransition countries to have a positive wage gap ( $6.5 \%$ and $5.4 \%$ respectively). A negative public-private wage gap was still mainly concentrated among countries that went through transition. Specifically, the gap was $-16 \%$ in Hungary and $-4.8 \%$ in the Czech Republic; all other transition countries fell somewhere in between, except for Romania and Latvia, where there was no gap [13].

\section{LIMITATIONS AND GAPS}

The inability to control for non-random selection of workers into the public and private sectors is a common limitation in public-private wage gap estimations for transition economies. Reported estimates may be affected by different statistical assumptions when attempting to quantify unobserved characteristics that may influence sector selection. Nevertheless, the few studies that have attempted to correct for employee sector selection (in Poland [6] and Yugoslavia [7]) and a study that used longitudinal employee data for Ukraine [2] confirm the existence of a public sector wage penalty during transition. Apart from employee self-selection, evidence on other selection issues and measurement errors on reported sector status is lacking. For example, it may be the case that better performing firms are the first to be privatized and/or that workers are confused over employers' ownership due to the speed of privatization [5]. Given that wholesale privatization implies ownership change even though most people do not actually change jobs, procedures that explore changes in the proportions among industry branches in the public sector caused mainly by privatization could correct for potential endogeneity of job moves [4]. Furthermore, analyses of cross-country comparisons of long-term trends in sectoral wage gaps during transition are hampered by data limitations, changes in survey methodology, sector definitions, and sample and variable selection [5].

Although post-communist economies share similar institutional backgrounds, countryspecific circumstances emerged during transition. Therefore, the sectoral wage gap may be affected by changes in public sector wage determination, minimum wages, government accountability and fiscal discipline, as well as hiring and firing procedures. Further understanding of the consequences of such institutional changes caused by transition requires additional analyses on multiple countries.

Finally, another avenue worth exploring concerns changes in wage patterns caused by changes in the labor market structure resulting from different privatization and restructuring methods. Policymakers could benefit from future analyses of the effects of privatization of certain industry branches or occupations on individual employee wages.

\section{SUMMARY AND POLICY ADVICE}

The transition from planned to market-based economies was characterized by a conversion of the labor market from public sector ownership to a competitive structure. In this context, the move away from centralized wage-setting (e.g. a wage grid imposed by the state) toward the wage-setting methods typical of market economies could be considered as a natural experiment, which may help to understand and adjust the wagesetting mechanisms in the public sector. 
A common finding from empirical studies, irrespective of the econometric method applied, is that public sector workers received lower wages than their private sector counterparts during the early period of transition. This is in contrast to developed market economies, where inequalities between public and private sector wages are mainly explained by sectoral differences in job and worker characteristics. Empirical evidence shows that greater wage inequality in the private than in the public sector caused a larger public-private sector wage gap for high earners than for low earners, especially during early transition. However, the public sector not only implemented a catch up with private sector wages during transition, but also saw a widening of its wage distribution.

Against this background, some key observations for policymakers regarding the implications of different wage-setting arrangements between the private and public sectors on wage inequality can be highlighted. Foremost is that competitive wages in the private sector attract highly educated workers away from public sector jobs, which suffer from greater wage compression. This may adversely affect public sector recruitment, performance, and worker turnover. It has been argued that this negative selection of highly educated workers in the public sector could lead to a deterioration in the quality of public services and economic efficiency. The literature provides evidence of increased incentives for the public sector to adjust wages, especially of skilled workers, once exposed to competition from the private sector. Empirical results also show the evolution of public-private sector wage differentials over the course of economic transition toward estimates obtained in developed market economies. Specifically, a decline in the public sector wage penalty and an increase in public sector wage inequality relative to the private sector has been observed in transition countries. Carefully designed wage policies should thus take account of comprehensive public to private sector wage distributions. In this way, policymakers could leverage different strategies to more effectively restructure public sector wages.

\section{Acknowledgments}

The author thanks two anonymous referees, and the IZA World of Labor editors for many helpful suggestions on earlier drafts. The author also thanks Richard Disney and Iva Tomić. The author draws heavily on previous work [1], [4], [5], [11], [12].

\section{Competing interests}

The IZA World of Labor project is committed to the IZA Guiding Principles of Research Integrity. The author declares to have observed these principles.

(C) Jelena Nikolic 


\section{REFERENCES}

\section{Further reading}

Disney, R. F., and A. Gosling. A New Method for Estimating Public Sector Pay "Premia": Evidence from Britain in the 1990s. Centre for Economic Policy Research Discussion Paper No. 3787, February 2003.

Nikolic, J., I. Tomić, and I. Rubil. "Pre-crisis reforms, austerity measures and the public-private wage gap in two emerging economies." Economic Systems 41:2 (2017): 248-265.

\section{Key references:}

[1] Lausev, J. Public-Private Earnings Differentials during Economic Transition in Hungary. Budapest Working Papers on the Labour Market No. BWP-201/2, 2012.

[2] Gorodnichenko, Y., and K. S. Peter. "Public sector pay and corruption: Measuring bribery from micro data." Journal of Public Economics 91:5-6 (2007): 963-991.

[3] Newell, A., and M. W. Socha. The Polish Wage Inequality Explosion. IZA Discussion Paper No. 2644, February 2007.

[4] Nikolic, J. "Effect of large-scale privatization on public sector pay gap in a transition economy." Economics of Transition 22:4 (2014): 759 -781.

[5] Lausev, J. "What has twenty years of public-private pay gap literature told us? Eastern European transitioning vs. developed economies." Journal of Economic Survey 28:3 (2014): 516-550.

[6] Adamchik, V. A., and A. S. Bedi. "Wage differentials between the public and the private sectors: Evidence from an economy in transition." Labour Economics 7:2 (2000): 203-224.

[7] Jovanovic, B., and M. M. Lokshin. "Wage differentials and state-private sector employment choice in Yugoslavia." Economics of Transition 11:3 (2003): 463-491.

[8] Telegdy, À. "The effect of the public sector wage increase on the public-private relative wages." In: Galasi, P., and G. Kézdi (eds). The Hungarian Labour Market 2006. Budapest: Institute of Economics, Hungarian Academy of Sciences, Hungarian Employment Foundation, 2006; pp. 60-68.

[9] Leping, K.-O. "Evolution of the public-private sector wage differential during transition in Estonia." Post-Communist Economies 18:4 (2006): 419-436.

[10] Gimpelson, V., A. Lukiyanova, and A. Sharunina. Estimating the Public-Private Wage Gap in Russia: What Does Quantile Regression Tell Us? National Research University Higher School of Economics Basic Research Program Working Papers Series No. 104/EC, 2015.

[11] Lausev, J. "Public sector pay gap in Serbia during large-scale privatisation, by educational qualification." Economic Annals LVII:192 (2012): 7-24.

[12] Lausev, J. "The effect of austerity measures on public-private sector wage gap in Hungary." In: Global Crisis to Economic Growth: Which Way to Take? Belgrade: University of Belgrade, 2012.

[13] De Castro, F., M. Salto, and H. Steiner. The Gap Between Public and Private Wages: New Evidence for the EU. European Economy Economic Papers No. 508, October 2013.

\section{Online extras}

The full reference list for this article is available from:

http://wol.iza.org/articles/wage-policies-in-the-public-sector-during-wholesale-privatization

View the evidence map for this article:

http://wol.iza.org/articles/wage-policies-in-the-public-sector-during-wholesale-privatization/map 